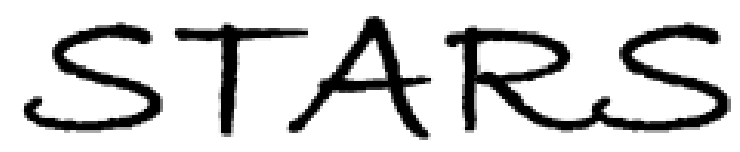

University of Central Florida

STARS

$1-1-2012$

\title{
Near-infrared photoresponse sensitization of solvent additive processed poly(3-hexylthiophene)/fullerene solar cells by a low band gap polymer
}

Zhongjian $\mathrm{Hu}$

University of Central Florida

Simon Tang

University of Central Florida

Anne Ahlvers

University of Central Florida

Saiful I. Khondaker

University of Central Florida

Andereiphifasquirkseat: https://stars.library.ucf.edu/facultybib2010

Universitu of fentral Floridalda Libraries http://library.ucf.edu

This Article is brought to you for free and open access by the Faculty Bibliography at STARS. It has been accepted for inclusion in Faculty Bibliography 2010s by an authorized administrator of STARS. For more information, please contact STARS@ucf.edu.

\section{Recommended Citation}

Hu, Zhongjian; Tang, Simon; Ahlvers, Anne; Khondaker, Saiful I.; and Gesquiere, Andre J., "Near-infrared photoresponse sensitization of solvent additive processed poly(3-hexylthiophene)/fullerene solar cells by a low band gap polymer" (2012). Faculty Bibliography 2010s. 2765.

https://stars.library.ucf.edu/facultybib2010/2765

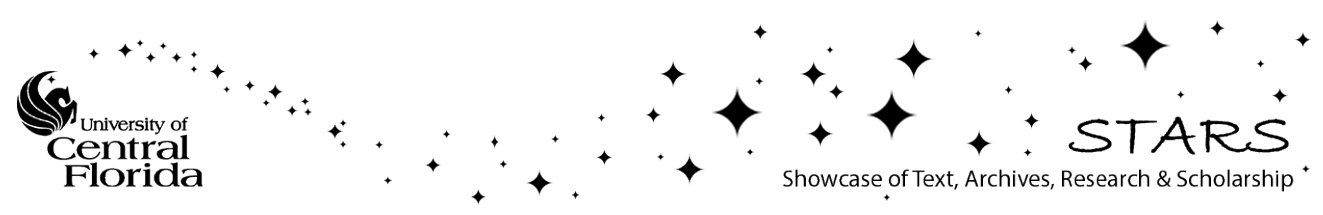




\section{Near-infrared photoresponse sensitization of solvent additive processed poly(3- hexylthiophene)/fullerene solar cells by a low band gap polymer}

Cite as: Appl. Phys. Lett. 101, 053308 (2012); https://doi.org/10.1063/1.4742143

Submitted: 18 June 2012 . Accepted: 19 July 2012 . Published Online: 02 August 2012

Zhongjian Hu, Simon Tang, Anne Ahlvers, Saiful I. Khondaker, and Andre J. Gesquiere

\section{ARTICLES YOU MAY BE INTERESTED IN}

Two-layer organic photovoltaic cell

Applied Physics Letters 48, 183 (1986); https://doi.org/10.1063/1.96937

Detailed Balance Limit of Efficiency of p-n Junction Solar Cells

Journal of Applied Physics 32, 510 (1961); https://doi.org/10.1063/1.1736034

Effect of traps on the performance of bulk heterojunction organic solar cells

Applied Physics Letters 91, 263505 (2007); https://doi.org/10.1063/1.2821368

\section{Applied Physics Reviews} Now accepting original research 


\title{
Near-infrared photoresponse sensitization of solvent additive processed poly(3-hexylthiophene)/fullerene solar cells by a low band gap polymer
}

\author{
Zhongjian Hu, ${ }^{1}$ Simon Tang, ${ }^{1}$ Anne Ahlvers, ${ }^{1,2}$ Saiful I. Khondaker, ${ }^{3}$ \\ and Andre J. Gesquiere ${ }^{1, a)}$ \\ ${ }^{1}$ NanoScience Technology Center, Department of Chemistry and CREOL, The College of Optics and Photonics, \\ University of Central Florida, 12424 Research Parkway Suite 400, Orlando, Florida 32826, USA \\ ${ }^{2}$ Department of Physics, Truman State University, 100 E Normal St., Kirksville, Missouri 63501, USA \\ ${ }^{3}$ NanoScience Technology Center, Department of Physics, University of Central Florida, 12424 Research \\ Parkway Suite 400, Orlando, Florida 32826, USA
}

(Received 18 June 2012; accepted 19 July 2012; published online 2 August 2012)

\begin{abstract}
With the aim of extending the photoresponse of the poly(3-hexylthiophene)/[6,6]-phenyl-C61-butyric acid methyl ester photovoltaic system into the near-infrared region, a low band gap polymer poly[2,1,3-benzothiadiazole-4,7-diyl[4,4-bis(2-ethylhexyl)-4H-cyclopenta[2,1-b:3,4-b']dithiophene-2, 6-diyl]] was incorporated to make ternary blend solar cells. Solvent additive 1,8-diiodooctane (DIO) was applied to optimize the phase separation in a one-step active layer preparation. Devices fabricated with DIO additive demonstrate an improvement of device power conversion efficiency by $17 \%$, which can be attributed to favorable microscopic structure of the ternary blend with 1:1:0.2 composition processed with DIO and extended absorption on the red side of the visible spectrum up to $900 \mathrm{~nm}$. C 2012 American Institute of Physics. [http://dx.doi.org/10.1063/1.4742143]
\end{abstract}

Since the first few reports of poly(3-hexylthiophene)/ $[6,6]$-phenyl-C61-butyric acid methyl ester ( $\left.\mathrm{P} 3 \mathrm{HT} / \mathrm{PC}_{60} \mathrm{BM}\right)$ solar cells with power conversion efficiency (PCE) of more than $4 \%,{ }^{1,2}$ great research effort has been devoted to the optimization of morphology, charge transport, device architecture, as well as improving the understanding of active layer photophysics. $^{3-7}$ It has been estimated that P3HT, with a band gap of $1.9 \mathrm{eV}$, can only absorb $\sim 27 \%$ of the solar photons, which strongly limits further device performance improvement of pure $\mathrm{P} 3 \mathrm{HT} / \mathrm{PC}_{60} \mathrm{BM}$ devices. ${ }^{8,9}$ Although the fabrication of tandem solar cells represents a promising approach to harvest more solar photons in a broad wavelength range, ${ }^{10}$ the wide applicability of this complicated multilayer structure has been hampered by difficulties in controlling the photocurrent balance between the front and back cells and by attenuation of light that can be absorbed by the back cell due to the presence of the front cell. ${ }^{11}$ In contrast to the tandem solar cell architecture, devices incorporating ternary blended active layers formed by incorporation of nearinfrared (NIR) sensitizers into the binary $\mathrm{P} 3 \mathrm{HT} / \mathrm{PC}_{60} \mathrm{BM}$ structure offer a more simple and versatile alternative approach in realizing a broad solar photon capture range. ${ }^{12-15}$ To realize effective sensitization in $\mathrm{P} 3 \mathrm{HT} / \mathrm{PC}_{60} \mathrm{BM}$ cells, the sensitizer should not only exhibit a complementary absorption to this material system but also have energy levels intermediate relative to those of $\mathrm{P} 3 \mathrm{HT}$ and $\mathrm{PC}_{60} \mathrm{BM}$ to facilitate charge transfer. ${ }^{12,13}$ Recently, researchers have shown incorporation of small far-red-absorbing dyes in the prototypical P3HT/ $\mathrm{PC}_{60} \mathrm{BM}$ cells ${ }^{12,13,15}$; however, less attention has been given to the development of ternary blended solar cells incorporating low band gap (LBG) polymers. ${ }^{14,16,17}$

In this letter, we report the photoresponse sensitization of $\mathrm{P} 3 \mathrm{HT} / \mathrm{PC}_{60} \mathrm{BM}$ solar cells with the LBG polymer poly[2,1,3-benzothiadiazole-4,7-diyl[4,4-bis(2-ethylhexyl)-4H-

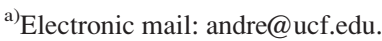

cyclopenta-[2,1-b:3,4-b']dithiophene-2,6-diyl]] (PCPDTBT) in the presence of a solvent additive, 1,8-diiodooctane (DIO). Compared to the optimized control devices $\mathrm{P} 3 \mathrm{HT} / \mathrm{PC}_{60} \mathrm{BM}$, the P3HT:PC ${ }_{60} \mathrm{BM}$ :PCPDTBT active layer with 1:1:0.2 composition (wt. ratio) and processed with DIO yields an improvement of $17 \%$ in PCE. The devices yield a shortcircuit current density $\left(\mathrm{J}_{\mathrm{sc}}\right)$ of $12.67 \mathrm{~mA} / \mathrm{cm}^{2}$, while the opencircuit voltage $\left(\mathrm{V}_{\mathrm{oc}}\right)$ and fill factor $(\mathrm{FF})$ remain similar to the control device at $0.55 \mathrm{~V}$ and 0.48 , respectively. We show that the accumulation of favorable microscopic structure of the ternary blend with 1:1:0.2 composition processed with DIO, together with extended absorption on the red side of the visible spectrum are responsible for the observed device performance improvement.

Figure 1 shows the chemical structures of PCPDTBT and the energy level diagram of device components. As can be seen, PCPDTBT exhibits intermediate energy levels with respect to $\mathrm{P} 3 \mathrm{HT}$ and $\mathrm{PC}_{60} \mathrm{BM}$. $\mathrm{P} 3 \mathrm{HT}$ and PCPDTBT were purchased from Rieke Metals and 1-material, respectively. $\mathrm{PC}_{60} \mathrm{BM}$, 1,2-dichlorobenzene (DCB) and DIO were obtained from Sigma Aldrich and used as received. To prepare devices without DIO additive, the blended solutions of P3HT, PCPDTBT, and $\mathrm{PC}_{60} \mathrm{BM}$ with different weight ratios were spin cast from DCB on top of a $40 \mathrm{~nm}$ thick poly(3,4-ethylenedioxythiophene):poly(styrenesulfonate) layer (PEDOT:PSS, Clevios P VP AI 4083, HC Starck) that was deposited on an ITO-coated glass substrate. Devices with DIO additive were prepared in the same way, but with addition of 3 vol. \% DIO to DCB. The active layer thickness is around $210 \mathrm{~nm}$ as measured with atomic force microscopy (AFM, Digital Instruments Dimension 3100). The $\mathrm{Ca}(25 \mathrm{~nm})$ and $\mathrm{Al}(80 \mathrm{~nm})$ cathode was thermally deposited sequentially at a rate of $\sim 0.6 \AA / s$. The active area of the devices is $0.066 \mathrm{~cm}^{2}$. Device performance was characterized under simulated $\mathrm{AM} 1.5 \mathrm{G}$ solar irradiation at $100 \mathrm{~mW} / \mathrm{cm}^{2}$ calibrated with a standard monocrystalline 

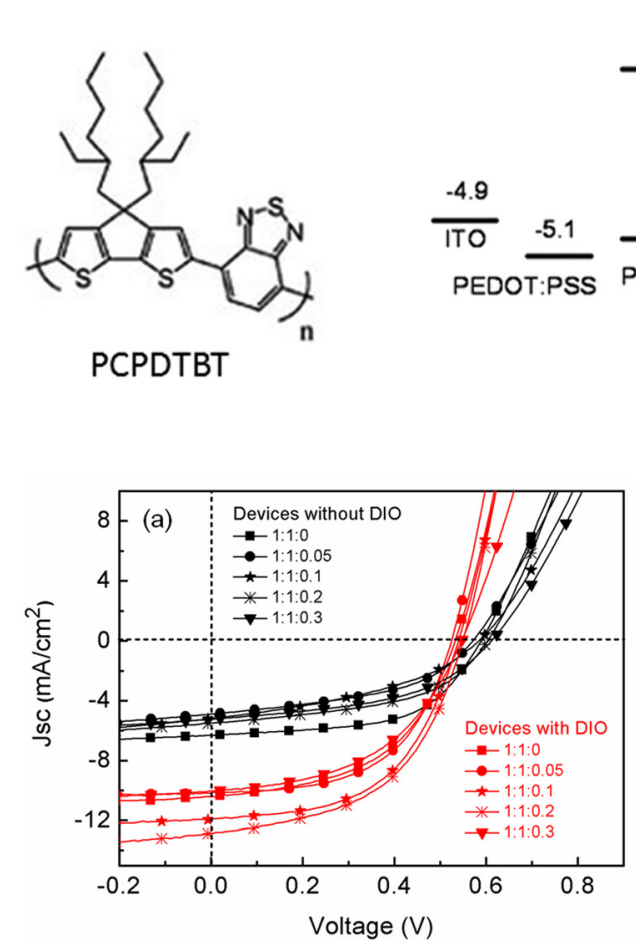
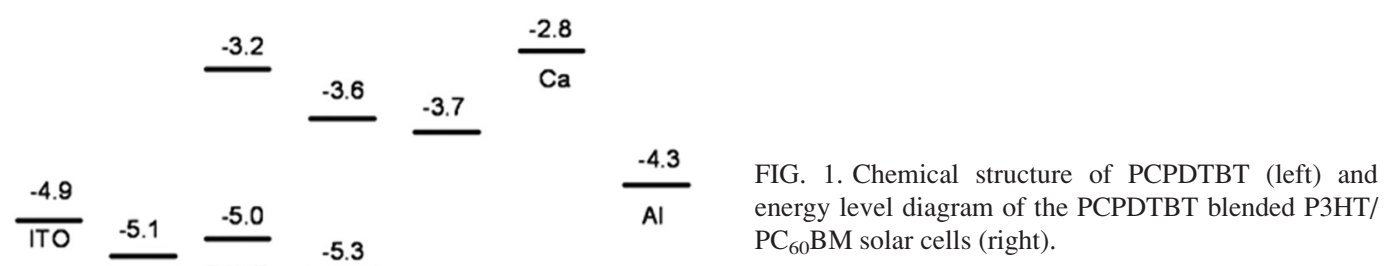
energy level diagram of the PCPDTBT blended P3HT/ $\mathrm{PC}_{60} \mathrm{BM}$ solar cells (right). silicon reference solar cell (Newport, 91150 V) with KG-5 visible color filter certificated by NIST (National Institute for Standards and Technology) to the ISO-17025 standard that is traceable to the National Renewable Energy Laboratory (NREL). External quantum efficiency (EQE) data was taken using the QE/IPCE Measurement kit (QE-PV-SI) from Newport.

The photocurrent density-voltage $(\mathrm{J}-\mathrm{V})$ characteristics of the devices studied herein are displayed in Figure 2(a). Figures of merit of the devices processed without and with DIO were extracted from these data and are summarized in Table I.

For the reference $\mathrm{P} 3 \mathrm{HT} / \mathrm{PC}_{60} \mathrm{BM}$ solar cell, the incorporation of solvent additive DIO increases $\mathrm{J}_{\mathrm{sc}}$ from $6.36 \mathrm{~mA} / \mathrm{cm}^{2}$ to $10.55 \mathrm{~mA} / \mathrm{cm}^{2}$ with a slight drop in $\mathrm{V}_{\mathrm{oc}}$ and $\mathrm{FF}$, resulting in an increase of PCE from $2.17 \%$ to $2.84 \%$.

Ternary blended solar cells processed in the absence of DIO exhibit lower efficiency than the corresponding reference $\mathrm{P} 3 \mathrm{HT} / \mathrm{PC}_{60} \mathrm{BM}$ solar cell (see Table I). Upon incorpora-

TABLE I. Device performance of solar cells with different PCPDTBT contents processed without and with DIO solvent additive.

\begin{tabular}{|c|c|c|c|c|c|}
\hline $\begin{array}{c}\text { P3HT:PC }{ }_{60} \text { BM:PCPDTBT } \\
\text { (wt. ratio) }\end{array}$ & $\begin{array}{l}\text { Processed with } \\
3 \text { vol. \% DIO }\end{array}$ & $\begin{array}{c}\mathrm{J}_{\mathrm{sc}} \\
\left(\mathrm{mA} / \mathrm{cm}^{2}\right)\end{array}$ & $\begin{array}{l}V_{o c} \\
(V)\end{array}$ & $\mathrm{FF}$ & $\begin{array}{l}\text { PCE } \\
(\%)\end{array}$ \\
\hline & No & 6.36 & 0.59 & 0.58 & 2.17 \\
\hline \multirow[t]{2}{*}{ 1:1:0 } & Yes & 10.55 & 0.55 & 0.49 & 2.84 \\
\hline & No & 4.60 & 0.58 & 0.49 & 1.32 \\
\hline \multirow[t]{2}{*}{ 1:1:0.05 } & Yes & 10.21 & 0.53 & 0.52 & 2.78 \\
\hline & No & 5.12 & 0.59 & 0.44 & 1.32 \\
\hline \multirow[t]{2}{*}{ 1:1:0.1 } & Yes & 11.84 & 0.53 & 0.50 & 3.13 \\
\hline & No & 5.55 & 0.58 & 0.52 & 1.57 \\
\hline \multirow[t]{2}{*}{ 1:1:0.2 } & Yes & 12.67 & 0.55 & 0.48 & 3.33 \\
\hline & No & 5.48 & 0.61 & 0.46 & 1.52 \\
\hline 1:1:0.3 & Yes & 10.03 & 0.55 & 0.50 & 2.75 \\
\hline
\end{tabular}

tion of PCPDTBT, the short-circuit current, fill factor and device PCE are all lowered with respect to that of the reference $\mathrm{P} 3 \mathrm{HT} / \mathrm{PC}_{60} \mathrm{BM}$ solar cell. This can be ascribed to the non-optimized film morphology due to the presence of PCPDTBT in the active layer, as discussed for the absorption data (Figure 3(a)) and the AFM data hereafter (Figure 4).

With regard to solar cells prepared with DIO, the device with the lowest PCPDTBT concentration (1:1:0.05 for P3HT:PC ${ }_{60} \mathrm{BM}:$ PCPDTBT) exhibits similar device performance as the reference cell. For the 1:1:0.2 PCPDTBT sensitized solar cell the device exhibits a $20 \%$ increase in $\mathrm{J}_{\mathrm{sc}}$, i.e., from $10.55 \mathrm{~mA} / \mathrm{cm}^{2}$ observed for the $\mathrm{P} 3 \mathrm{HT} / \mathrm{PC}_{60} \mathrm{BM}$ optimized control solar cell to $12.67 \mathrm{~mA} / \mathrm{cm}^{2}$ for the $1: 1: 0.2$ ternary blended solar cell. Meanwhile $\mathrm{V}_{\mathrm{oc}}$ and FF remain similar to the optimized reference cell, leading to an efficiency of $3.33 \%$ for the 1:1:0.2 PCPDTBT sensitized solar cell compared to $2.84 \%$ for the reference $\mathrm{P} 3 \mathrm{HT} / \mathrm{PC}_{60} \mathrm{BM}$ solar cell incorporating DIO. Note that there is a small decrease of $\mathrm{V}_{\mathrm{oc}}$ for the DIO processed devices relative to the devices without DIO, which is due to the increase in energy of the highest occupied molecular orbital (HOMO) energy level of crystalline P3HT structures. ${ }^{12,18,19}$

The EQE data displayed in Figure 2(b) for the devices fabricated with DIO additive indicate the origin of the observed $20 \%$ increase in $\mathrm{J}_{\mathrm{sc}}$ and $17 \%$ increase in PCE for the 1:1:0.2 ternary blended solar cell. At the blending ratio of $1: 1: 0.2$, the EQE at $700 \mathrm{~nm}$ reaches $23 \%$ due to the PCPDTBT sensitization of the NIR photoresponse in these ternary blended devices. Meanwhile the EQE contribution from $\mathrm{P} 3 \mathrm{HT} / \mathrm{PC}_{60} \mathrm{BM}$ absorption (ranging from $300 \mathrm{~nm}$ to $650 \mathrm{~nm}$ ) remains unchanged. The solar cell photocurrent density $\left(\mathrm{J}_{\mathrm{sc}}\right)$ can be calculated by integrating the EQE spectra with the AM 1.5 G solar spectrum using Eq. (1)

$$
\mathrm{J}_{\mathrm{sc}}=\frac{\mathrm{q}}{h \mathrm{c}} \int_{\lambda_{1}}^{\lambda_{2}} \operatorname{EQE}(\lambda) \cdot \mathrm{P}_{\mathrm{in}}(\lambda) \cdot \lambda \mathrm{d} \lambda,
$$



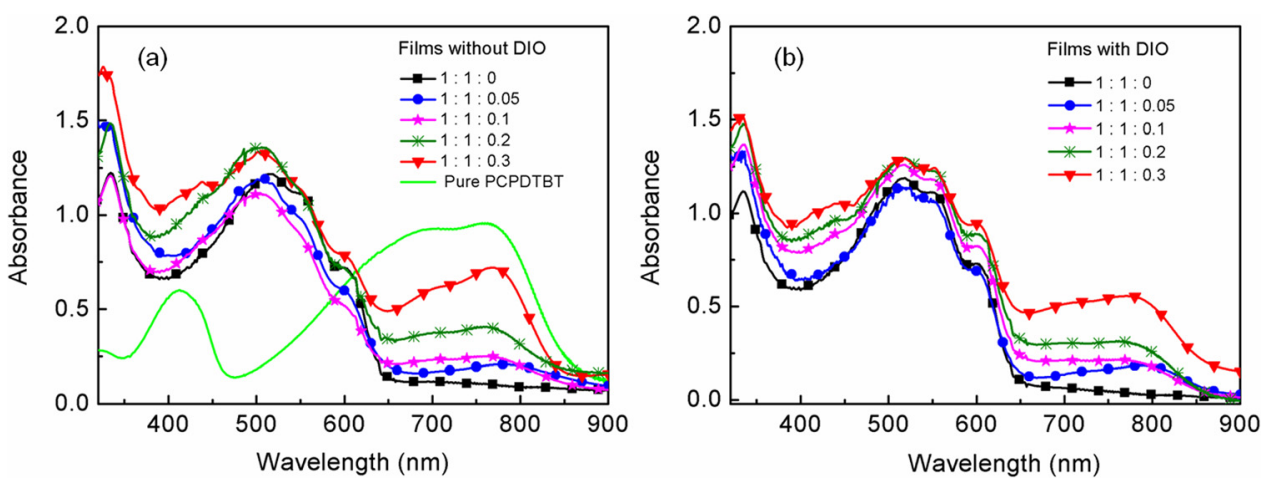

FIG. 3. Absorption spectra of films prepared without (a) and with solvent additive DIO (b). The weight ratios of P3HT:PC ${ }_{60}$ BM:PCPDTBT are indicated. Absorption spectrum of a pure PCPDTBT film spin cast from dichlorobenzene is included in (a). where $\mathrm{q}$ is the elementary charge, $h$ Plank's constant, $\mathrm{c}$ the speed of light, $\lambda_{1}$ and $\lambda_{2}$ are wavelength limits of EQE spectrum, $\operatorname{EQE}(\lambda)$ the external quantum efficiency as a function of wavelength $(\lambda), \mathrm{P}_{\mathrm{in}}(\lambda)$ spectral irradiance under standard AM $1.5 \mathrm{G}$ solar illumination. ${ }^{20}$ According to Eq. (1), the $\mathrm{J}_{\mathrm{sc}}$ values for the control device and the 1:1:0.2 ternary blended device are estimated to be $10.22 \mathrm{~mA} / \mathrm{cm}^{2}$ and $12.57 \mathrm{~mA} / \mathrm{cm}^{2}$, respectively. These results match well with the $\mathrm{J}-\mathrm{V}$ results shown above.

The role of the active layer absorption profiles in these device characteristics was studied first. Figure 3 presents the absorption spectra of $\mathrm{P} 3 \mathrm{HT} / \mathrm{PC}_{60} \mathrm{BM}$ films with different PCPDTBT concentrations and a pure PCPDTBT film processed without and with DIO. With increasing PCPDTBT concentration (up to weight ratios for P3HT:PC ${ }_{60} \mathrm{BM}$ :PCPDTBT of $1: 1: 0.3)$, the ternary blend exhibits an increasing absorbance in the range of $650 \mathrm{~nm}$ to $900 \mathrm{~nm}$ due to PCPDTBT absorption, supporting the observations made from the EQE data. The resulting broad absorption wavelength range from $300 \mathrm{~nm}$ to $900 \mathrm{~nm}$ of the ternary blend films was expected to generate higher photocurrent output than the $\mathrm{P} 3 \mathrm{HT} / \mathrm{PC}_{60} \mathrm{BM}$ control device, although this is only the case for the 1:1:0.1 and 1:1:0.2 ternary blended devices due to the effects of active layer morphology at lower blending ratios. The absorption data also hint at morphological effects in the active layer as a function of composition and processing that play a role in the observations made for the J-V data. For films processed without DIO additive, direct addition of PCPDTBT leads to a pronounced blue shift of the P3HT absorption maximum from
$515 \mathrm{~nm}$ for the control $\mathrm{P} 3 \mathrm{HT} / \mathrm{PC}_{60} \mathrm{BM}$ film to about $505 \mathrm{~nm}$ for all the PCPDTBT incorporated films (Figure 3(a)). In addition, the vibronic shoulders of the P3HT absorption at $550 \mathrm{~nm}$ and $600 \mathrm{~nm}$ that are due to the interchain interactions become less defined in the presence of PCPDTBT, although peak positions do not shift in those cases. These observations indicate a disruption of the P3HT ordered structure by PCPDTBT, which can be verified by the AFM data shown hereafter. In comparison, the introduction of DIO can recover the crystalline structure of P3HT as can be observed from absorption profiles of films with DIO shown in Figure 3(b), which is attributed to microscopic phase separation in the presence of DIO. ${ }^{21}$ The P3HT absorption maximum and vibronic characteristics are not significantly affected by the addition of PCPDTBT in the presence of DIO.

The active layer morphology was studied further by AFM. Figure 4 presents AFM topography and phase images of the reference $\mathrm{P} 3 \mathrm{HT} / \mathrm{PC}_{60} \mathrm{BM}$ solar cells and the PCPDTBT ternary blended devices (1:1:0.2 and 1:1:0.3 P3HT:PC ${ }_{60}$ BM:PCPDTBT ratios). As clearly shown in Figures 4(a),(f), and 4(b), (g), direct incorporation of PCPDTBT (i.e., without adding DIO) with a ratio of 1:1:0.2 induces a relatively smoother surface and disrupted phase separation compared to the reference $\mathrm{P} 3 \mathrm{HT} / \mathrm{PC}_{60} \mathrm{BM}$ cell, which are indicative of a decrease of $\mathrm{P} 3 \mathrm{HT}$ crystallinity since a rough surface of $\mathrm{P} 3 \mathrm{HT} / \mathrm{PC}_{60} \mathrm{BM}$ is usually attributed to $\mathrm{P} 3 \mathrm{HT}$ crystallization into ordered structures. ${ }^{1,22}$ This result is in accordance with the blue shift of the absorption maximum of P3HT due to the presence of PCPDTBT. For the reference
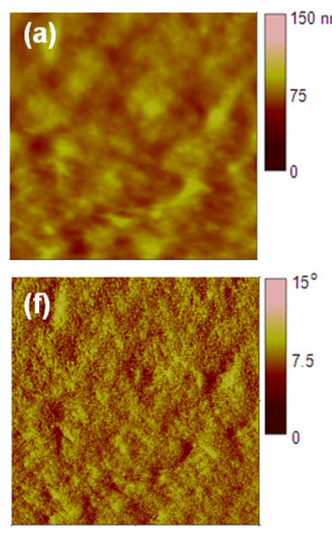
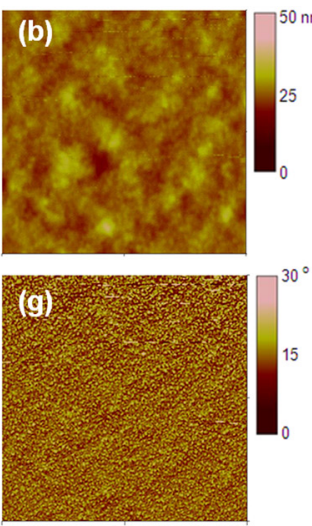
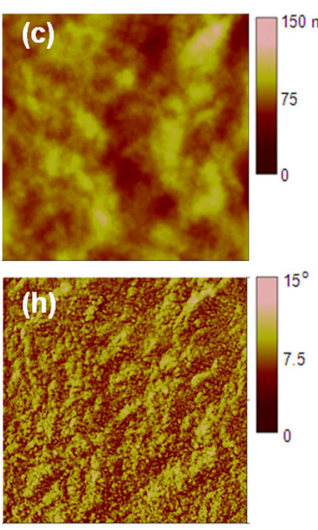
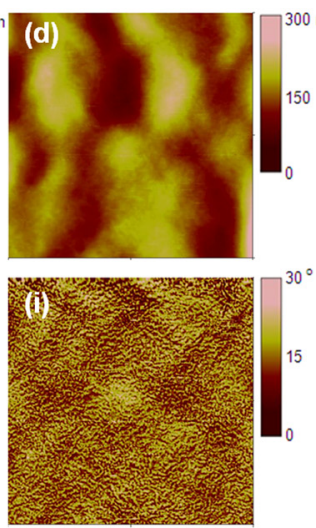

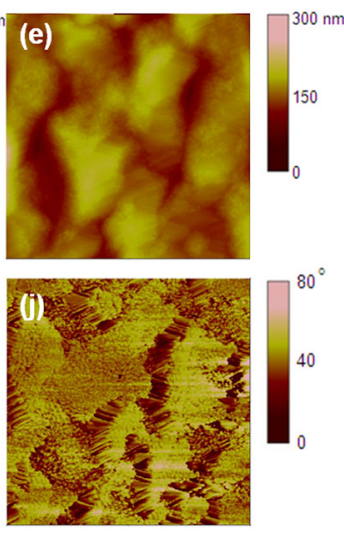

FIG. 4. AFM topography images of (a) $\mathrm{P} 3 \mathrm{HT} / \mathrm{PC}_{60} \mathrm{BM}$ cell without $\mathrm{DIO}$, (b) P3HT:PC 60 BM:PCPDTBT = 1:1:0.2 cell without DIO, (c) P3HT/PC 60 BM cell with DIO, (d) P3HT:PC ${ }_{60} \mathrm{BM}: \mathrm{PCPDTBT}=1: 1: 0.2$ cell with $\mathrm{DIO}$, (e) $\mathrm{P} 3 \mathrm{HT}: \mathrm{PC}_{60} \mathrm{BM}: \mathrm{PCPDTBT}=1: 1: 0.3$ cell with DIO. Corresponding AFM phase images (f)-(j) are shown below each topography image. The scan size for all the images is $5 \times 5 \mu \mathrm{m}^{2}$. 
$\mathrm{P} 3 \mathrm{HT} / \mathrm{PC}_{60} \mathrm{BM}$ cells, the addition of DIO induces a slightly rougher surface and a finer phase separation of the active layer (Figures 4(c) and 4(h)), which is favorable for photoinduced charge separation and subsequent charge transport. With the incorporation of DIO in the 1:1:0.2 PCPDTBT incorporated cell, a rough surface topography is also observed accompanied with fine phase separation and fibrillar structure as shown in Figures 4(d) and 4(i). This favorable microscopic structure of the ternary blend together with the complementary absorption and appropriate energy levels of PCPDTBT is responsible for the observed device performance improvement. When the PCPDTBT content increases up to $1: 1: 0.3$, macrosize phase separation can be observed (Figures 4(e) and 4(j)), which is assumed to be responsible for the observed drop in device performance for this active layer composition.

In summary, we have demonstrated optimization of ternary blended active layers for OPVs using the additive DIO. The solvent additive DIO serves to optimize the microscopic structure of the active layer. With this approach the incorporation of PCPDTBT in $\mathrm{P} 3 \mathrm{HT} / \mathrm{PC}_{60} \mathrm{BM}$ cells with a weight ratio of $1: 1: 0.2$ for $\mathrm{P} 3 \mathrm{HT}: \mathrm{PC}_{60} \mathrm{BM}$ : PCPDTBT lead to a $20 \%$ increase in short-circuit current density and a $17 \%$ increase in device performance in the presence of DIO additive, compared to the optimized reference $\mathrm{P} 3 \mathrm{HT} / \mathrm{PC}_{60} \mathrm{BM}$ device. Our results indicate that with the proper control of the morphology of ternary blended materials, NIR absorbing conjugated polymers can be effectively used to efficiently extend the photon capture range of polymer solar cells.

The authors gratefully acknowledge the National Science Foundation (NSF) for financial support of this work through a CAREER award (CBET-0746210, AJG) and through award ECCS-0801924 (SIK, AJG). Anne Ahlvers thanks NSF for research support through REU site EEC0851987. We would like to thank Dr. Yi Liao and Dr. Win- ston V. Schoenfeld for access to their facilities for device measurements.

${ }^{1}$ G. Li, V. Shrotriya, J. S. Huang, Y. Yao, T. Moriarty, K. Emery, and Y. Yang, Nat. Mater. 4(11), 864 (2005).

${ }^{2}$ W. L. Ma, C. Y. Yang, X. Gong, K. Lee, and A. J. Heeger, Adv. Funct. Mater. 15(10), 1617 (2005).

${ }^{3}$ L. M. Chen, Z. Xu, Z. R. Hong, and Y. Yang, J. Mater. Chem. 20(13), 2575 (2010).

${ }^{4}$ B. C. Thompson and J. M. J. Frechet, Angew. Chem. Int. Ed. 47(1), 58 (2008).

${ }^{5}$ V. D. Mihailetchi, H. X. Xie, B. de Boer, L. J. A. Koster, and P. W. M. Blom, Adv. Funct. Mater. 16(5), 699 (2006).

${ }^{6}$ L. M. Chen, Z. R. Hong, G. Li, and Y. Yang, Adv. Mater. 21(14-15), 1434 (2009).

${ }^{7}$ T. M. Clarke and J. R. Durrant, Chem. Rev. 110(11), 6736 (2010).

${ }^{8}$ C. J. Brabec, S. Gowrisanker, J. J. M. Halls, D. Laird, S. J. Jia, and S. P. Williams, Adv. Mater. 22(34), 3839 (2010).

${ }^{9}$ G. Dennler, M. C. Scharber, and C. J. Brabec, Adv. Mater. 21(13), 1323 (2009).

${ }^{10}$ J. Y. Kim, K. Lee, N. E. Coates, D. Moses, T. Q. Nguyen, M. Dante, and A. J. Heeger, Science 317(5835), 222 (2007).

${ }^{11}$ F. Meillaud, A. Shah, C. Droz, E. Vallat-Sauvain, and C. Miazza, Sol. Energy Mater. Sol. C 90(18-19), 2952 (2006).

${ }^{12}$ J. Peet, A. B. Tamayo, X. D. Dang, J. H. Seo, and T. Q. Nguyen, Appl Phys. Lett. 93(16), 163306 (2008).

${ }^{13}$ J. H. Huang, M. Velusamy, K. C. Ho, J. T. Lin, and C. W. Chu, J. Mater. Chem. 20(14), 2820 (2010).

${ }^{14}$ M. Koppe, H. J. Egelhaaf, G. Dennler, M. C. Scharber, C. J. Brabec, P. Schilinsky, and C. N. Hoth, Adv. Funct. Mater. 20(2), 338 (2010).

${ }^{15}$ S. Honda, T. Nogami, H. Ohkita, H. Benten, and S. Ito, ACS Appl. Mater. Interfaces 1(4), 804 (2009).

${ }^{16}$ S. J. Park, J. M. Cho, W. B. Byun, J. C. Lee, W. S. Shin, I. N. Kang, S. J. Moon, and S. K. Lee, J. Polym. Sci. Pol. Chem. 49(20), 4416 (2011).

${ }^{17}$ C. H. Chen, C. H. Hsieh, M. Dubosc, Y. J. Cheng, and C. S. Su, Macromolecules 43(2), 697 (2010).

${ }^{18}$ W. C. Tsoi, S. J. Spencer, L. Yang, A. M. Ballantyne, P. G. Nicholson, A. Turnbull, A. G. Shard, C. E. Murphy, D. D. C. Bradley, J. Nelson, and J. S. Kim, Macromolecules 44(8), 2944 (2011).

${ }^{19}$ K. Vandewal, A. Gadisa, W. D. Oosterbaan, S. Bertho, F. Banishoeib, I. Van Severen, L. Lutsen, T. J. Cleij, D. Vanderzande, and J. V. Manca, Adv. Funct. Mater. 18(14), 2064 (2008).

${ }^{20}$ West Conshoken American Society for Testing and Materials (ASTM) Standard G159, PA, USA.

${ }^{21}$ X. Bai and S. Holdcroft, Macromolecules 26(17), 4457 (1993).

${ }^{22} \mathrm{G}$. Li, V. Shrotriya, Y. Yao, J. S. Huang, and Y. Yang, J. Mater. Chem. 17(30), 3126 (2007). 